\title{
RAPID IMMUNOPEROXIDASE MONOLAYER ASSAY (IPMA) FOR DETECTION AND TITRATION OF FOOT AND MOUTH DISEASE ANTIBODLES IN SHEEP IN COMPARISON WITH SNT AND ELISA
}

\author{
Eman. M. A. \\ Department of Foot and Mouth disease, Serum and \\ VaccIne Research Instltute. Abassla. Calco. P.O.Box 131
}

\begin{abstract}
This siudy describes the evaluation of (mmunoperoxidase monolayer assay (IPMA) for detecting antibodies against serolype $O 1 / 93$ Fool and Moutl Disease vinus in sera of infected, vaccinaled and randoin field sera of sheep. The IPMA resulls were compared with that obtained by serum neutralization test (SNT) and indtrect enzyme-liviked immunosorbent assay (ELISA). All injected vaccinated sheep sera lesled posilive by SNT and ELISA. were posiluve by IPMA with a mean llters of 1.35.1.77and 1.83 $\log _{10}$ TCID $_{50}$ one monlh post experimentclly infecled sheep or sheep vaccinated with tnaclluated monovalent gel adjuvani serolype O1/93 FMD utur vaccine. 30 out of 50 field slieep sera lested posllive by bolh ELISA and IPMA. Oul of the 30 posiltue sera 27 (90\%) revealed neutralizing anlibody llters of 0.6 to $1.5 \log _{10} T_{C I D_{50}}$ in experninlally infecled or vacchated sheep. anthodles against serolype $01 / 93$ could be delected 5 to 7 days following infection or vacchation by ELISA and IPMA. The agreenient between IPMA and ELISA was 100\% but il was 90\% belween IPMA and SNT in field samples. the applicablliy of IPMA as speclfic and rapld for delection of FMD anlibodles was discussed.
\end{abstract}

Keywords: Immunoperaxddaes monolayer assay (IPMA), ELISA, SNT, serolype O1) 93 FMDV antibodies. infecled. vaccinaled and fields sheep.

\section{INTRODUCTION}

Because of the early response agalnst Foot and Mouth disease (FMD) vlrus in sheep sera charactralzed by low or even absence of neutralizing anubodles. and the clinlcal signs in sheep also occurred malnily subclinlcally. a raptd. spectic and sensluve lest is l'equired for detectlon of antibody. ELISA could be detecled carly anLbodies but the lechnique need automaUc ELISA 
reader to esUmate lise results. Immunoperoxldase monolayer assay (IPMA) is a vlsual method and have proven to be an easy method and avallable tool for dlagnosis of several infectlous diseases such as Bovlne viral Diarhea, Rinderpest, Cytomegalo virus, Influenza and Pseudorables viral unfection. IPMA permils the demonstration of antigens in various types of cells and nxed tissues. Most laboratorles are routlnely using IPMA for detection of antibodles especiaily early antibodtes (Afghar et al., 1989., Drew 1995, Horner et al, 1995. Yoon et al., 1985, Nodeldk et al., 1996, OW, 1996. Sollman et al., 1997 and Deregt and prins 1998). The alm of this study was to evaluate a newly developed IPMA which is based on ELISA assay In which Egyptan serotype 01/93 FMD for Infected BHK21 clone 13 monolayer cultuated in 96 well flat plates were used as antigen to detect antbodles in sera of infected. vacclnated, random neld sheep, atrlal to detect the early antbodtes in Infecled and yaccinated sheep. The results of IPMA were compared with the results of ELISA. SNT. Data on the prevalence of serotype 01/93 antuodies in random neld sheep are presented.

\section{MATERLAL AND METHODES}

\section{Serum samples:}

A total of stxty serum saniples were collecled from experimently Infected. vaccinated sheep of 1.5-2 years old hve of eaclt. Nso nity sera collected from apparinlly heallhy sheep of 1-2 years old ralsed at sharquia governerate in endemlc area with FMD. Sera were collected from expermintally infected and vacclnated at 3,5,6,7,15.30 days post infection and/or vacclination. The sera were inactivaled at $56^{\circ} \mathrm{C}$ for 30 minutes and stored at $-20^{\circ} \mathrm{C}$ unull used.

\section{Immunoperoxddaso monolayer assay (IPMN)}

Im nunoperoxidase inonolayer assay (IPMA) was periromed as described by Warls et al., 1990. Brelefly. BHK 21 clone 13 monolayer cells were grown to confluency in 96 well fat ussue culture plate (Nunc. Denmark). The confluency cells were inoculated with 100 TCID50 serotype 01/93 FMDV and incubated at $37^{\circ} \mathrm{C}$ for 24 hours. Plates washed once with $0.15 \mathrm{M}$ phosphate buffer saline contalning $0.1 \%$ Tween 20 and dried for 24 minutes $\mathrm{In}$ laminar flow and stored at $-20^{\circ} \mathrm{C}$ In sealed plastic bag. Belor using the plate for tesung antlbodles. the plate were nxed in freshly prepared cold muxture of $50 \%$ acetone and $50 \%$ methanol at $4^{\circ} \mathrm{C}$ for 45 minutes. plates washed 3 Umes with washing buffer (PBS containing 0.1 tween 20 and $0.5 \%$ bovine serum Albumin BSA), incubated with lested serum (diluted two fold In PBS contalning $0.1 \%$ tween 20 and $0.5 \%$ Bovine Serun Nbumin (BSA) at $37^{\circ} \mathrm{C}$ for one hour then washed 5 llines. Antisheep conjugated 
with peroxidase in is dlluthon of 1:3000 was added and Incubated at $37^{\circ} \mathrm{C}$ for one hour. The plates washed 5 times. Then substrate (nitrated mixture of $0.15 \mathrm{gn}$ ) of 3.3 dlamine benzldine letrahydinchloride in $50 \mathrm{ml}$ of $1 \%$ sodlum acelate soln $\mathrm{pH} 5.1 \mathrm{ml}$ of $\mathrm{N}$ sodiun hydroxide and $0.6 \mathrm{ml}$ of $30 \% \mathrm{H2O2}$ ) was added and incubated at $37^{\circ} \mathrm{C}$ for 20 minutes. Postlve reaction was seen as clear red-brown stalned sheet of cells and no staining was observed in negatuve reaction. Posluve and negative control sheep sera were included in each plate.

\section{Vurus neutrallization test :}

The mirio neutralizallon test was applled using BHK-21 monolayers as described by (Golding at el., 1976). Each serum sainple was tested agalnst serotype $01 / 93$ FMD virus, and the titer was calcubatcd accrding to Rced and Meunch (1938).

\section{Lndurect Enzyrae Linked Immunosorbent Assag (Indtrect ELISA):}

The proceduce was carried oul as described by Hamblln et al., (1986) and Shawky et al., (2000). The optimum ditution of the antugen used for coating was 1/160, sheep conjugate 1/ 3000 .

\section{RESULTS}

Detectlon llialt:

The geometrical nean titers (reciprocal of mean Ulers) against serolype 01/93 root and mout) disease vlrus 30 days followling experhmental infected, vaccinated five sliecp in each vere 1.83,1.77, $1.35 \log _{10}$ TCID $_{50}$ in inlecled and $1.52 .1 .41 .1 .14 \log _{10}$ TCID $_{50}$ in vaccinated tested by IPMLA. ELISA and SNT' respecuvely (Table 1,2\&3). Nll Infected and vaccinated sheep tested by IPMA revealed anubody tlers ranged from 1.35 to $1.95 \log _{10} \mathrm{TCID}_{50}$ with a percentage of (100\%) at 30 days followi.,g infectlon or vaccination. The detectlon limlts by IPMA were as high as that of ELISA (Table 1).

\section{Experimentally Infected and vacclnated sheep}

The IPMA and IELISA first demonstrated antibodies against serotype $01 / 93$ around 5 10 7 days post infection or vaccination with uters ranged hetween 0.6 to $0.9 \log _{10}$ TCID $_{50}$ (Taule 1 \&2). Whereas, neutralizlng anubodies Rrst detected al 7 to 10 days post infection or vacclinalion wlth a titers ranged between 0.6 to 0.75 (Table 3).

Marsoura, Vet. Med. J.

Vol, VI, No. 2, 2005 


\section{Random sera collected from endemlc arca with FMD}

The results of random nifly sera collected from apparently healthy sheep of $1-2$ years old ralsed at Sharquilea Govemorate in endemic area with FMD revealed that 30 sera (60\%) had anUbody uters ranged from 0.9 to 1.8 by IPMA and 0.75 to $1.65 \log _{10}$ TCID 50 by IELISA. Whereas. 27 out of $30(90 \%)$ tested positlve by IPMA and IELISA had neutralizing antibody titers ranged from 0.6 to $1.5 \log _{10} T_{C I D}$ (Table 4). The correlation between IPMA positive and the results obtalned by IELISA and SNT were demonstrated in Lable 5.

\section{DISCUSSION}

Immunoperoxddase monolayer assay (IPMA) has been reported as rellable. senslllve and speciflc technique for the detection of early developed viral antugen for rafld dlagnosis of Cytomegalovins. Influenza, and respiratory syncytial Infectoris (Gleaves et al., 1984, Graham et al., 1966, Greninl et al., 1983, Waris et al., 1990.01E, 1996 and Anon 1997). Based on the spec incity, detection linit, results obtained to the response of early Infection or vaccination and random neld serum samples, the newly developed IMPA are xellable test for the detectlon of antubodles agalnst serotype O1/93 FMD virus. The evaluation study in infected and vaccinated sheep revealed that, all positlve sera tested by ELISA were also posillve by IMPA will speciliclity 100\%. The IPMA technlque was able to detect anubudy responses 5 to 7 days following experimental inrecled and vaccinated sheep. The results abtalned from sheep sera collecled from area endemlc with FMD revealed that 30 out 50 (60\%) sera had allubody ulers ranged belween 1.1 lo 2.1 by IPMA and ELISA. Out of 30 posltye sera 27 (90\%) revealed neutralizing antuody Uters ranged from 0.9 to 1.7. The decrease in positve percentage detected by SNT could be as results of sheep were sampled in early tines affer vaccination or infecton. The early antlbodles against serotype 01/93 FMDV delected at 5 lo 7 days following infection and or vaccination by IPMA and ELISA technlques could not be delecled by SNT. Our Investigation revealed that IPMA and ELISA are the test of choice for detecung early antibodies agalnst FMD wrus In infected and vaccinated anlmals. The advantage of IPMA test is its results did not need automauc reader as that In ELISA (Grenlni et al., 1983. Gleaves et al., 1984). The need at least of two (rained persons to be interpreted the results of IPMA to reduce the subjectlvity of reading of test results is considered disadvantage of the test (Wellenberg et al., 1999). SImllar study were conducted by other authors which used IPMA for detection of antibodies (Sollman et al., 1997. Walrs et al., 1990) or comparison between IPMA and ELISA for detection of antibodles in Infected and vaccinated animals (Van Ourschot et al., 1986, Kelly et al., 1988 and Nodflujk et al., 1998). The prescull study revealed that Immunoperoxldase monolayer assay (IPMA) can be used for tise screening 
antibodles agalnst foor and mouth disease virus as an alternative technique to ELISA. In conclusion, the IPMA is a reliable pracucal test for the screening FMD virus antubodies, and it could be used as a useful altemative technique to ELISA 11 Infected. vaccinated and randon held serum samples. 
Table 1: Antibody titers against serotype $01 / 93$ detected in sera of infected and vaccinated sheep tested by Immunoperoxidase monolayer assay (IPMA)

\begin{tabular}{|c|c|c|c|c|c|c|c|c|c|c|}
\hline \multirow{4}{*}{$\begin{array}{l}\text { Days post } \\
\text { Infection } \\
\text { and } \\
\text { vaccination }\end{array}$} & \multicolumn{10}{|c|}{ Antibody tilers against serotype 01/93 FMDV in inlected and vaccinaled sheep } \\
\hline & \multicolumn{10}{|c|}{ Animal number } \\
\hline & \multicolumn{2}{|c|}{1} & \multicolumn{2}{|c|}{2} & \multicolumn{2}{|c|}{3} & \multicolumn{2}{|c|}{4} & \multicolumn{2}{|c|}{5} \\
\hline & In. & Vac. & in. & Vac. & In. & Vac. & in. & Vac. & $\ln$. & Vac. \\
\hline 3 days & $0.3^{*}$ & 0.0 & 0.15 & 0.3 & 0.0 & 0.0 & 0.15 & 0.30 & 0.30 & 0.15 \\
\hline 4 days & $0 . \overline{45}$ & $0 . \overline{30}$ & 0.30 & 0.3 & 0.15 & 0.0 & 0.3 & 0.30 & 0.45 & 0.15 \\
\hline 5 days & 0.6 & 0.3 & 0.6 & 0.6 & 0.75 & 0.45 & 0.45 & 0.30 & 0.6 & 0.3 \\
\hline 6 days & 0.6 & 0.45 & 0.6 & 0.6 & 0.6 & 0.45 & 0.6 & 0.45 & 0.9 & 0.45 \\
\hline 7 days & 0.9 & 0.6 & 0.9 & 0.9 & 0.75 & 0.6 & 0.75 & 0.6 & 0.9 & $0 . \overline{75}$ \\
\hline 15 days & $1 . \overline{35}$ & 1.2 & 1.5 & 1.2 & 1.5 & 1.2 & 1.5 & 1.2 & 1.35 & 1.2 \\
\hline 30 days & 1.5 & 1.35 & 1.8 & 1.5 & 1.95 & 1.75 & 1.95 & $\overline{1.5}$ & 1.95 & 1.5 \\
\hline
\end{tabular}

Table 2: Antlbody titers against serotype 01/93 detected in sera of infected and vaccinated sheep tested by Indirect immunosorbent assay (ELISA)

\begin{tabular}{|c|c|c|c|c|c|c|c|c|c|c|}
\hline \multirow{4}{*}{$\begin{array}{l}\text { Days posi } \\
\text { infeclion } \\
\text { \&or } \\
\text { vacoination }\end{array}$} & \multicolumn{10}{|c|}{ Anlibooy titers agains serolype $01 / 93$ FMDV in infected and vaccinated sheep } \\
\hline & \multicolumn{10}{|c|}{ Ánimal number } \\
\hline & \multicolumn{2}{|c|}{1} & \multicolumn{2}{|c|}{2} & \multicolumn{2}{|c|}{3} & \multicolumn{2}{|c|}{4} & \multicolumn{2}{|c|}{5} \\
\hline & in. & Vac. & In. & $\overline{\mathrm{Vac}}$. & In. & vac. & In. & Vac. & $\ln$. & Var. \\
\hline 3 days & $0.3^{*}$ & 0.0 & 0.15 & 0.3 & 0.0 & 0.0 & 0.15 & 0.30 & 0.30 & 0.15 \\
\hline 4 days & $\overline{0.45}$ & 0.30 & 0.30 & 0.3 & 0.15 & 0.0 & 0.3 & 0.30 & 0.45 & 0.15 \\
\hline 5 days & 0.6 & 0.3 & $\overline{0.6}$ & $\overline{0.6}$ & 0.0 & 0.15 & 0.45 & 0.30 & 0.6 & 0.3 \\
\hline 6 days & 0.6 & 0.45 & 0.6 & 0.6 & 0.6 & 0.3 & 0.6 & 0.45 & 0.9 & 0.45 \\
\hline 7 days & 0.9 & 0.6 & 0.9 & 0.9 & 0.75 & 0.6 & 0.75 & 0.6 & 0.9 & 0.75 \\
\hline 15 days & 1.2 & 1.2 & 1.5 & 1.2 & 1.5 & 0.9 & 1.5 & 1.2 & $1 . \overline{35}$ & 1.2 \\
\hline 30 days & 1.5 & 1.35 & $\overline{1.8}$ & 1.35 & 1.95 & 1.5 & 1.95 & 1.35 & 1.65 & 1.5 \\
\hline
\end{tabular}


Table 3: Antibody titers against serolype $01 / 93$ detected in sera of infected and vaccinated sheep tested by serum neutrallzation test (SNT)

\begin{tabular}{|c|c|c|c|c|c|c|c|c|c|c|}
\hline \multirow{4}{*}{$\begin{array}{l}\text { Oays posi } \\
\text { infection. } \\
\text { \&or } \\
\text { vaccination }\end{array}$} & \multicolumn{10}{|c|}{ Antibody liters againsl serolype 01/93 FMDV in infecled and vaccinaled sheep } \\
\hline & \multicolumn{10}{|c|}{ Animal number } \\
\hline & \multicolumn{2}{|c|}{$\overline{1}$} & \multicolumn{2}{|c|}{2} & \multicolumn{2}{|c|}{3} & \multicolumn{2}{|c|}{4} & \multicolumn{2}{|c|}{5} \\
\hline & in. & Vac. & In. & Vac. & In. & Vac. & $\ln$. & Vac. & in. & Vac. \\
\hline 3 days & $0.15^{*}$ & 0.0 & 0.15 & 0.15 & 0.0 & 0.0 & 0.15 & 0.0 & 0.0 & 0.0 \\
\hline 4 days & $\overline{0.15}$ & 0.0 & 0.30 & 0.3 & 0.15 & 0.0 & 0.3 & 0.0 & 0.45 & 0.15 \\
\hline 5 days & 0.15 & $0 . \overline{3}$ & 0.45 & $\overline{0.45}$ & 0.6 & 0.15 & 0.45 & $0 . \overline{30}$ & $\overline{0.45}$ & 0.3 \\
\hline 6 days & 0.3 & 0.3 & $0 . \overline{45}$ & 0.45 & 0.6 & 0.3 & 0.45 & 0.45 & 0.45 & 0.3 \\
\hline 7 days & 0.6 & 0.45 & 0.6 & 0.6 & 0.75 & 0.6 & 0.6 & 0.6 & 0.6 & 0.45 \\
\hline 15 deys & 1.05 & 0.9 & 1.2 & 1.05 & 1.05 & 0.9 & 1.05 & 0.9 & 1.05 & 0.9 \\
\hline 30 days & $1 . \overline{2}$ & 1.05 & 1.35 & 1.2 & $1 . \overline{35}$ & 1.2 & 1.5 & 1.05 & 1.35 & 1.2 \\
\hline
\end{tabular}

In.: Inlecled sheep Vac.: vaccinated sheep

": Anlibody lilers expressed as $\log _{10} T C D_{50}$

Table 4: Antibody responses against serotype 01/93 FMD virus in random samples collected from Sharkla Governorate as determined by IPMA, IELISA and SNT

\begin{tabular}{|c|c|c|}
\hline \multirow{2}{*}{\begin{tabular}{c} 
Type of serological test \\
\cline { 2 - 3 }
\end{tabular}} & Postlive & Tolal No of sera tesled 50 \\
\hline IPMA & $30 / 50$ & $60 \%$ \\
\hline ELISA & $30 / 50$ & $60 \%$ \\
\hline SNT & $27 / 50$ & $54 \%$ \\
\hline
\end{tabular}

Table 5: Correlation between positive IPMA, ELISA and SNT Correlation between IPMA, ELISA and SNT

\begin{tabular}{|c|c|c|}
\hline Out of the total positive by IPMA & $\begin{array}{c}\text { The positive \% by } \\
\text { ELISA }\end{array}$ & $\begin{array}{c}\text { The positive } \% \text { by } \\
\text { SNT }\end{array}$ \\
\hline 30 & $30(100 \%)$ & $27 / 30(90 \%)$ \\
\hline
\end{tabular}




\section{REFERENCES}

Afshar, A.; Dulac, G. C. and Bouffard, A.(1989) : Appllcation of peroxidase labelled antibody assays for detection of porcine lgG antubodles to hog cholera and bovine viral dirrhea viruses, J. Virol. Methods, 23:253-262.

Anon. (1997) : I'porclne reproductive and resplratory syndrome in northem Ireland. Veterinary Record 140:139.

Deregt, D. and Prins, 8. (1998) : Amunoclonal antubody based Immunoperoxydase monolayer (micro-Isolation) assay for detection of type 1 and lype 2 bovine viral cliarrhea viruses. Call . J. Vet. Res., 62: 152-155.

Drew, 'r. W. (1995) : Conmpalatuve serulogy of purche reproduclive and respilatury syndrome in eight European laboratortes, using lmmunoperoxddase monnlayer assay and comyme-

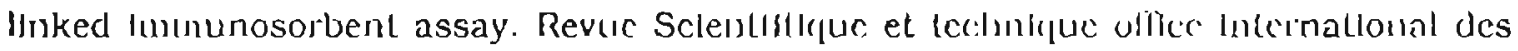
pizoolles 14: 761-775.

Gleaves, C. A; T. F. Smitli; E. A. Shuster and G. R. pearson (1984) : Rapid cletelion of yluegalovirus in MRC-5 ells inoulated wllh urine spechnens by using low speed cnlrifugation and monoclonal antibocly to an early antigen. J.Clin. Microblul 19: 917-919.

Goldlng, S. M.; Hedger, R. S. and Tabbot, P. (1976) : Rachlal Immuno-diffusion and serum neutrallzatson technlques for the assay of antibodies to swine vesiculid disease. Res. Vet. Scl. 20,142-147.

Graham, R. C.; I. Luudholm and M. J. ICarnovsky (1965) : CyLochemlal denionstration of peroxldase activily with 3-amono 9-ethylcarbazole. J. Histuchem. Cylochcm. 13:150-152.

GrenlnI, R.: M. Douatl; A. M. Donati: A. Moronl; L. Franchl and F. Rumplanesl (1983) : Rapid iminunoperoxldase assay for detection of respiratory synytlal virus lis nasopharyngeal serelluns. J.Clln. Microblol. 18:947-949.

Hambun C.: Barnett I. T. R. and Crowther G. R. (1986) : $\Lambda$ new enzyme- Linked linnmuosorIJent assay (FLISA) for the Jetection of antlbodles against foot and mouth diseasc vlius: II Applic:illous. J. Iinmuniol. Meth., 93، 123-129.

Horner, G. W.; Tham, IS. M. orr, D.: Ralston, J.; Rowe, S. aud Houghton, T. (1995) : Conlparison of an antigen caplure enzyme-linked assay with reverse transcriptionpolymerase chaln reaction and cell culture Immunoperoxydase lest for the dlagnosis of iuninant pestivirus Infectlon. Vet. Microblol., 43: 75-84.

Kelly D. J. Wong P. W. Gan E. Lewis G. E. Jr. (1988) : Coinparalive evaluation of the indirect immunoperoxldase test for the serodlagnosls of rckettslal disease. An J Trop Med Hyg 38:400-406.

Nodelifk, G., Wensvoort, G., Kroese, B., Van Leengoed, L., Colljn, E. and Verheljden, J. (1996) : Comparison of a commercial ELISA and an Immunoperoxidase monolayer assay to deted anllbudiesdlsected agalnst porclne respiratory and reproduchue syndromir 
virus. Veterlnary Microblology 49: 285-295.

Offle International dea Eplzootles., (1996) : Manual of Standards for Dlagnosic tests vacclns. 3rded. OlE paris. France ISBN 92-9044-423-1.

Reed, L. J. and Muench, H. (1938) : A siniple method for estimaung fifty percent end polnt. Amer. J. Hyg., 27:493-497.

Shawky M., EL-Watany H., A Bamira El-KJlany and Roghdy O H (2000) : Evaluation of Relationshlps Among ELISA. Dot ELISA and Agar Gel Pseclpltation tests in the detection of 3 CD Antigen of FMDV. The Egyptian Journal of Immunology. Vol. 7[1]. 97-103.

Soliman,A.K., Douglas, M.W., Sallb, A.W., Shehata, AE.D., Arthur, R.R., Botrog, B.A.M., (1997) : Application of an immunoperoxidase monolayer assay for the detector of arboviral antibodles. J.Vir. Meth. 65,147-151.

Van olrschot J. T.; H. J. Rxtha; P. J. L. M. Moenen; J. M. A. Pol and D.Van Zaane (198B): Differentation of serum anubodles from plgs vacchnated and Infected with Aujeszky.s stsease virus by compelitve enzyme inimunoassay. J. Gen. VIrol. 67:1179-1182.

Wark M.: T. Zlegler: M. KJFlvita and $O$. Ruusikanen (1990) : Rapld detection of resplratury syncyual virus and enfluenza A.wrus in cell cultures by iminunoperoxidase stalming with monoclonal antubodles. J. Clin. Icroblol 28: 1159-1162.

Wellenberg, G. J., Van RoolJ, E. M. A, Malasan. J. and Van Otrschot, J. T. (1999) : EvaluaLon of newly developed immunoperoxidase monolayer assay for detecting of antibodies agajnst Bovlne herpes vlrus 4. Clinical and diagnostic Laboratory Imınunology. 6. 447$45 \mathrm{I}$

Yoon, K. J., Zlummerman, J. J., Swenson, S. L., McGlnleg, M. J., Eemlsse, K. A., Brevtk, A., Rhinehart, L. L., Frey, M. L., Hil, H. T. and Platt, K. B. (1995) ; Characlertzation of the humoral immune response to prrclne reproductive and respiratory syndrome (PRRS) virus Infection. Joumal of Veterlnary Dlagnosuc Invesugation 7:305-312. 
إستخدام طريقة الأمينوبيروكسيدز على خلايا وحيدة الطبقة لتحديد ومعايرة الأجسام المناعية المضادة لفيروس الحمى القلاعية ومقارنتها بطريقتى الأليزا والسيرم المتعادل

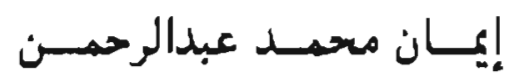

توضح هذه الدراسة تقييم طريقه الأمينوبيروكسيدز على خلايا رحبدة الطبتة في لتحديد رمعايرة الأجسام الناعية

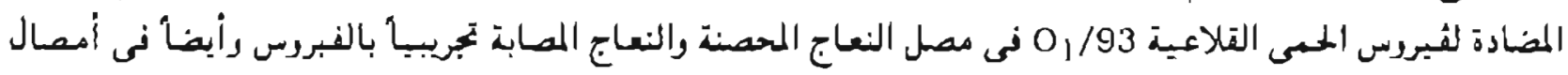

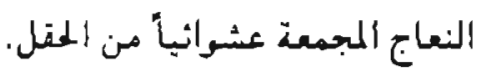

رلقد تم مفارنة النتانج التحصـل علبها من الأمينصيروكسيدز على خلايا وحيدة الطبقة مع النتانج المتحصل عليها

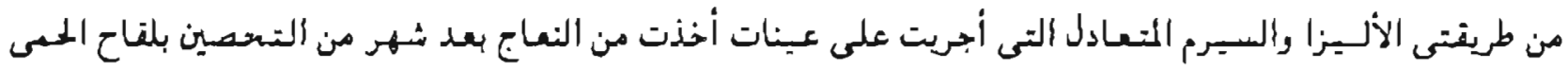

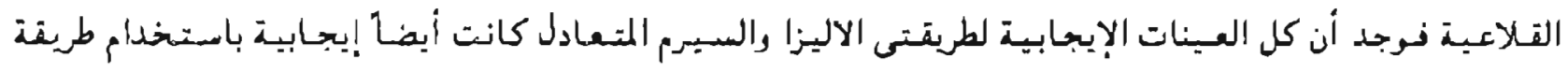
الأمينرييروكسيدز بقوة عيارية TCID

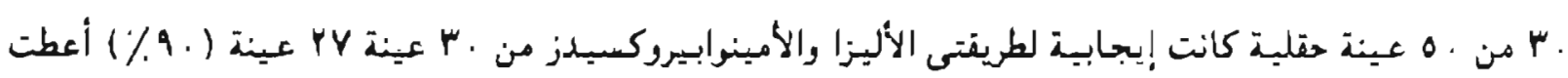

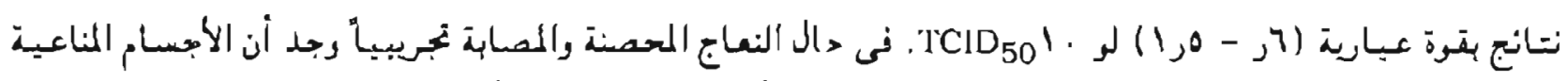

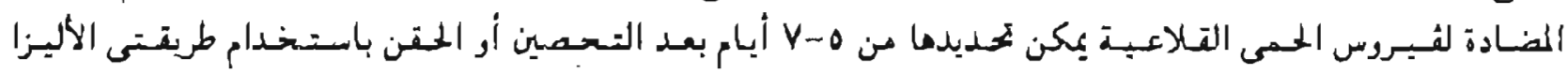

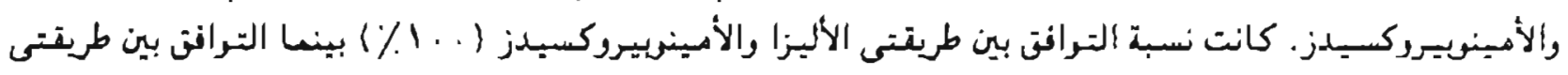

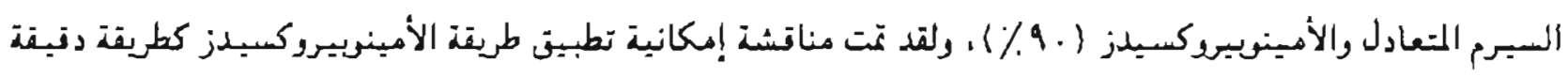

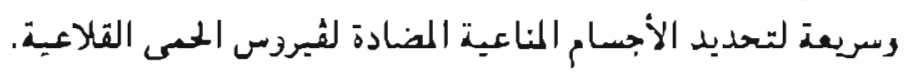

